\title{
Resistance as a means of creating accountability in child welfare institutions
}

\author{
Susanne Severinsson and Ann-Marie Markström
}

\section{Linköping University Post Print}

\section{Tweet}

N.B.: When citing this work, cite the original article.

Original Publication:

Susanne Severinsson and Ann-Marie Markström, Resistance as a means of creating accountability in child welfare institutions, 2015, Child \& Family Social Work, (20), 1.

http://dx.doi.org/10.1111/cfs.12070

Copyright: Wiley: 24 months

http://eu.wiley.com/WileyCDA/

Postprint available at: Linköping University Electronic Press

http://urn.kb.se/resolve?urn=urn:nbn:se:liu:diva-92174 


\section{Resistance as a means of creating accountability in child welfare institutions}

This article investigates the identity constructions of youths who are objects of special interventions in the area of child welfare. The aim of the article is to explore the various dimensions of resistance to institutional identities among youths in special schools and foster-care institutions. Interviews were conducted with adolescents aged between 12 and 15, identified as having social, emotional and behavioural difficulties. The analysis generates knowledge about society's interventions as well as how adolescents respond to offered institutional identities by adopting different kinds of discursive resistance. The article highlights the different types of discursive resistance that adolescents use to present themselves as accountable individuals and discusses the importance of considering resistance as a positive force rather than as something that must be defeated.

Keywords: accountability, adolescent, child welfare institution, clientification, identity, resistance

\section{INTRODUCTION}

Social child welfare has the societal assignment to ensure children's rights to a safe upbringing and to meet their needs. Society makes use of out-of-home placements in special schools and foster institutions in order to solve what are often defined as individual problems (Kelly 2006; Thomas \& Holland 2010; Severinsson 2010). A point of departure for placing adolescents in social welfare institutions is that they have some kind of psychosocial problem that can be solved by treatment and/or education. The social order, routines and rules of such institutions reflect an underlying rationale, for instance, for what constitutes desirable qualities and behaviour in the institution (Goffman 1968).

However, little research has been carried out into how adolescents in child welfare talk about their experiences of out-of-home placements. In this article, we look at how adolescents, aged between 12 and15, understand and position themselves in relation to the institution. Drawing on an ethnographic study of out-of-home placements in special schools and foster institutions for young people identified with social, emotional and behavioral difficulties, this article aims to explore how the adolescents talk about themselves in interviews in relation to the categorisations of the institutions. Furthermore, the article aims to explore the various dimensions of resistance to offered institutional identities. 


\section{THEORETICAL FRAMEWORK AND PREVIOUS RESEARCH}

The study is grounded in a social constructionist perspective, which suggests that the constructions of aspects like identity are relational and located in language and discourse (Best 1994), i.e. language and talk that contributes to the production and reproduction of different images of identity are not neutral. The interventional settings in this study are regarded as institutional practices in which discursive constructions of identity are formed through interaction. Since identity is seen as being formed by interactional processes within the framework of various contexts and discourses, it also becomes possible to talk about different identities linked to different environments and contexts (Gubrium \& Holstein 2001). Identities thus become a consequence of an institutional practice. Identity is negotiated and transformed in unequal power relations, for instance between professionals and youths (McMurray et al. 2011). Järvinen and Mik-Meyer (2003) call this 'creating a client' (p. 9) since people first have to be categorised to be entitled to benefits from social welfare institutions.

Furthermore, embedded and taken-for-granted assumptions about youths in out-of-home placements or other institutions require an adjustment to the role of a client. Goffman (1990) describes this as 'working consensus'. The status of 'working consensus' not only means accepting a role as an individual with problems, but also affects a young person's identity formation. However, working consensus can be questioned by 'clients' who want to distance themselves from the institutionally embedded problem of identities and clientification. If competing points of views are expressed as to how the youths are defined, they are negotiated by the participants (Juhila et al. 2003; Hall et al. 2006). This distancing from the problem categories can be understood as 'resistance'. Goffman (1968) describes many different strategies of resistance and defines resistance as practices that emerge when desires and needs are confronted by demands from outside. The youths' protests thus provide an opportunity for meetings and negotiations about what should be done and about who the young people are supposed to become (Gubrium \& Holstein 2001).

\section{Resistance to categorisation and 'client identities'}

Resistance can be interpreted from an individual/psychological perspective, from a more collective/ interactional perspective or from a structural point of view, and can be overt or covert, intentional or unintentional (McFadden 1995; Högberg 2011; Russell 2011). 
Structural resistance is often seen as organised open protest and more or less systematic striving against the power structures and social orders of dominating discourses. Giroux (1983) argues that it is important to include the actor's own views and meanings when discussing resistance. His point of view is that resistance emanates from an underlying critique of power relations within a repressive system in which individuals are subordinated, such as that of a social institution. However, as people are not always aware of nor can explain their actions of resistance, Giroux argues that it is important to relate resistance to the particular context in which it occurs.

Willis' (1977) study of working-class boys, which is perhaps the best-known study on the subject, shows how boys struggle for independence and individuality within the institution. In line with Willis' study, Trondman (1999) and Högberg (2011) studied teenagers' resistance to school. They argue that teenagers strive against a power that both disqualifies and tries to change them from something unwanted into something 'normal' in a context in which others have the right to decide on matters relating to their everyday lives. However, the complexity of identity formations becomes evident when the youths sometimes accept and conform to schooling when it favours their own desires and purposes. In addition, Severinsson (2010) shows how child welfare settings are organised to meet this kind of open protest using humour, flexibility and close relationships to maintain consensus in a situation characterised by conflict and ambivalence.

Resistance can be interpreted from an individual/psychological perspective, from a more collective/ interactional perspective or from a structural point of view, and can be overt or covert, intentional or unintentional (McFadden 1995; Högberg 2011; Russell 2011). Structural resistance is often seen as an organised and more or less systematic striving against the power structures and social orders of dominating discourses.

Psychological resistance emanates from psychodynamic theory, where resistance is seen as a way of defending unwanted feelings. Even though they sometimes hinder people, they are also necessary to keep people 'going'. In practice, there are often discussions about how to break through the resistance in order to work with emotions and thoughts (Forrester et al. 2008). An example of a psychological definition of the concept as something unwanted is when Forrester et al. (2008) evaluate the effectiveness of 'motivating interviewing' and conclude that resistance is a big problem within child and family social work' (p. 1316) because it hinders progress. 
Resistance in institutions can be expressed physically, emotionally, socially and verbally (Markström 2011). McLeod (2007) shows that youths use different control strategies when interviewed by social workers: avoidance, active or passive resistance, aggression, fantasy, denial, exaggeration or changing the subject.

In this article, we use the concept of discursive resistance to illustrate how the youths talk about their identities in relation to the institution. Certain problem constructions can lead to resistance to offered support linked to certain identities (Juhila 2004; Järvinen \& Mik-Meyer 2003; van Nijnatten 2010). Here resistance is characterised by opposing problem categorisation without having to comply. This kind of discursive resistance is constructed when people talk to each other and is not an open protest as in the studies of Willis (1977) and Giroux (1983). Positioning oneself as accountable in a conversation can be an active choice and a way of deconstructing categories (van Nijnatten 2010). The term accountability is useful in the analysis of arenas in social work. According to Hall et al. (2006), accountable means to be seen as morally responsible and able to justify your judgement or action. Using this concept here shows that the youths included in this interview study are seen as responsible actors.

Identity construction is a process of being categorised as belonging to, for instance, special institutions. Categories in social work practice are connected to different kinds of failures that people have to accept and 'become' before they can be helped. A certain way of labelling the situation or the individual is established through categorisation. 'Categorization involves a set of processes which result in facts, opinions or circumstances being established as one type of category rather than another' (Hall et al. 2006, p.15).

Categorisation helps the participants to understand and manage their everyday lives. However, as categorisation also involves identity construction, people can sometimes be stigmatised. Ungar $(2001,2005)$ highlights the importance of strengthening resilience rather than creating problem identities. Ungar (2004) talks about the importance of maintaining or becoming a positive identity and its function as resilience. Children's positive views of themselves have also influenced the results of societal interventions (Eide \& Winger 2005) in that a positive identity makes them less vulnerable to ill-treatment (Cairns \& Brannan 2005).

People can protest against the described identities and refuse to make a categorisation to their own. In welfare institutions, there are ongoing processes of both clientification (Cedersund \& Säljö 1993) and declientification (Messmer \& Hitzler 2011). For example, McMurray et al. (2011) show that youths reject stigmatised identities by seeing themselves as different to others in care. It is possible to see positive identity as a protective mechanism (McMurray et al. 2011). 
It is also important to recognise the logic of the youths and to see their views of themselves as part of the solution (Munford \& Sanders 2008) - something that has not been addressed to any great extent in previous research. Accordingly, it would be interesting to study how youths talk about themselves, because this could reveal how the logic of negative or positive identities is created. In this article, we therefore highlight how youths talk about themselves in interviews in relation to categorisations and clientification connected to the institution. In this context, the main focus is on the dimensions of discursive resistance to stigmatised identities and how these are expressed in the interviews.

\section{METHOD}

The article draws on a part of ethnographic study of youths in three institutional settings in the south of Sweden - a foster home with its own school, a small school for youths and a home for assessment and treatment without its own school. These settings were selected because they represented three different ways of organising education and treatment for adolescents. The empirical material presented in this article consists of 16 audio taped interviews with adolescents between 12 and 15 years of age (eleven boys and five girls). The interviews were conducted in the end of the one year long field study.

The young people concerned had been placed in these institutions because they had been assessed as having some kind of psychosocial or behavioural problems and were supposed to be changed and corrected during their stay, i.e. placing adolescents in these settings might also solidify a problematic identity (Severinsson 2010). It was not easy to motivate these young people to talk to the researcher at the beginning of the field studies (cf. McLeod 2007). Several of them had bad experiences of adults in general and of officials in particular. The ethnographic field study was a prerequisite to get access to the teenagers and to get them motivated to do an interview with the researcher. However, by the end of the fieldwork, many of the youths seemed to have gained confidence in the researcher and wanted to take part in the study. Anyone who wanted to be interviewed (16 of 30) was included in the study. Their parents also gave their consent. The interviews were conducted in a separate room at the institution. The interviews varied between 30 and 60 minutes in length and were transcribed verbatim.

'Active interviewing' (Holstein \& Gubrium 1995) was used for the interviews in order to encourage the adolescents to talk about themselves and the settings in general. The interviews were similar to an everyday conversation. In addition, the point of departure for this study is that an interview always is co-constructed. The interviews presented in this article focus on 
the teenagers talk about themselves in relation to the setting in an interview. When the interviews took place, it was not obvious that the interviews would also reveal accounts about identity. The interviews were about everyday life, their experiences and thoughts concerning the institution. The interviewer was not "looking for" resistance when the interviews were conducted. Later, in the analysis, it became clear that in interviews with young people in welfare settings, the question about identity in relation to the institution was important.

\section{Analysis}

This article presents an analysis that focuses on social constructions of identity transformation. This kind of analysis, inspired by Juhila et al. (2003), Hall et al. (2006), scrutinises social work and its implications for clients' identity work. A detailed approach was applied to the transcription, i.e. repetitions, sighs, laughter etc. were included (Wood \& Kroger 2000). The researchers read and re-read the transcriptions separately, compared them and tried to identify themes or patterns that described aspects of the studied phenomenon.

The first step in the analysis was to look for talk when the adolescents and interviewer's talk showed identity constructions in general in relation to the institution. The second step was to identify different themes in the accounts ( for instance about themselves before and today, or about relations) and the third step was to analyse the different kinds of talking in these themes, here interpreted more specifically as different kind of talk against stigmatising identities. The analysis focuses on accounts that show the dominant statements/images of identities and how the accounts could be interpreted as different kind of discursive resistance to stigmatising identities in relation to their placement in an institution. The results of the third analytical step, namely what is at stake concerning 'troubled' categorisations and identities (Juhila 2004), are presented in this article. The interviews were conducted in Swedish; the excerpts that are presented in the results have been translated.

\section{RESULTS}

In this section, we address how the youths talked about and positioned themselves and others in terms of being normal and/or deviant and how this was constructed in relation to their situation today, i.e. that they were placed in an institution. The analysis revealed a variety of responses that expressed and argued how they adopted or resisted institutional categorisations and identities of them as deviants and clients. 
We first present examples of statements that show how those interviewed 'accepted' the normal-deviant dichotomy or clientification, i.e. acceptance of a client identity. Further examples illustrate how the youths expressed resistance, argued against stigmatised identities and used different responses to resist a client identity in order to present themselves as competent and accountable individuals. These responses included total rejection, resistance through secondary adjustment, using time as a starting point, non-participation as a resource and others' bad behaviour.

\section{Total adjustment}

In some of the interviews, the youths talk in terms of accepting the social order and rules of the institution and the positive implications of staying in the institution, i.e. something that we interpret as total adjustment (Goffman 1968). The interviews mediate that the adolescents do think that they belong to this specific setting, for example, by saying that other adolescents are similar to themselves, i.e. they have some kind of problem and need to be placed out of the home. In the following example, Alba, aged 14, talks about which category of people is placed at the institution and what she thinks about that:

S: What's best about being here?

A: Oh, getting to know people like yourself.

$\mathrm{S}: \mathrm{Mm}$. Is that good?

A: Yes, because they understand you better than someone who doesn't have this kind of problem. $(\mathrm{S}=$ the interviewer in all the examples)

Alba seems to think that she is understood by others with the same kinds of problems as she has. She says that she gets 'to know people like yourself' and that she is not alone with her troubles. She also talks about similarities with other youths. In this example, she appears to accept that she is like other 'troubled' youths. This kind of acceptance not only confirms a client identity, but also ensures support.

Another example of what we interpret as total adjustment, is when Alex, aged 13, talks about compliance and learning to 'behave and not make difficulties':

\section{S: What kind of help do you need?}

A: What kind of help I need? (Yes) It's like this. I sort of, try to learn to behave and stuff. (Mm) I will learn to behave and not make difficulties and so on. 
He says that he tries 'to learn to behave' and he accepts the demands of the institution as in the previous example. Here Alex talks about himself as a good client doing his best to fit into the institution and 'to learn to behave'. Both examples show actors who express that they have knowledge about the demands of the institution that can be used to their own advantage but can also be interpreted as total adjustment.

\section{Total rejection}

Some statements are characterised by the defence of a 'problem' or deviant behaviour and statements that show that they are not going to change, i.e. the youth expresses a rejection to a change of identity. In the following example, Jonathan states that although he is capable of changing his behaviour, he does not want to do this:

S: You told me you are a satanist and all that. How does that fit with the goals here?

J: I don't know, but that would be possible to change, but I don't want to change that. It's my thing, you know.

Jonathan says that to be a satanist is his 'thing', which indicates that it is a part of him. He implies that he knows that this is not desirable behaviour. Other teenagers talk about how they resisted being placed in an institution from the beginning and that they were 'pissed off' and 'very negative towards this place from the start'. In the following example, Noah (12 years) talks about how he tried to resist the social order:

S: What can you decide by yourself?

$\mathrm{N}$ : Nothing. Except my stuff like keys and such things. If I give my things to the staff. Sometimes you have to give them to the staff so that they don't disappear (Yes). But I have them in my jacket. I have the keys and the bus ticket and my wallet in my jacket.

The excerpt shows a boy who first says he can not decide anything, but he can refuse to give his belongings to the staff - especially the bus ticket, which also controls the opportunity to leave. To defy the instruction from the staff and keep his belongings - 'I have them in my jacket' could be interpreted as some kind of open protest but also a total rejection to admit that he is a person who could not be responsible for his things.

Of course, there are differences between total adjustment and total rejection. Although the first examples of total adjustment imply possibilities for the youths to obtain professional 
support, there is also a risk of taught helplessness and a need for help from others. The latter example of total rejection could lead to exclusion, in that the provided efforts would never be accepted (cf. Russell 2011). In spite of these obvious practical implications, there are similarities in the two positions. In the quoted cases of total adjustment and total rejection, the informants accept the offered identities as good or bad clients. In the first examples, the girls adjust to the institution's demands; in the latter examples, the boys continue their 'undesirable' behaviour, i.e. behave as 'clients'.

Some of the responses indicate something other than total adjustment or total rejection, however. For example, some of the teenagers' responses towards the institutions are more nuanced, which shows that they are able to resist clientification.

\section{Resistance through secondary adjustment}

One type of response found in the interviews is a kind of compliance to get something they want. Here, the youths' desires to 'get out' can be interpreted as secondary adjustment (cf. Goffman 1967). To 'get out' or 'move back home' is something that all the youths talk about in the interviews. In their talk about this, they show an understanding that the only possibility of reaching that goal is to do the 'right things', i.e. follow the social order of the institution. In one of the interviews, 14-year-old Jonathan described the investigation the social workers conducted when he arrived at the institution and what he thought was the goal.

S: How is this investigation done? You said that there are three meetings, but how it is done? How do they investigate? How can you discover that?

J: (sigh) Yeah, you come here because you have done stupid things so they check what you say. How much you shape up. The whole investigation is about making you shape up and trust what they say and so on.

Jonathan seems to distance himself when talking about life in the institution, as though it does not really concern him. He expresses that he has worked out what is expected of him, 'to make you shape up and to trust what they say'. He knows what it is all about and what to he has to do to be a good client. Twelve-year-old Daniel also expresses that he knows what is expected of him:

S: Why do you go to this school and not to an ordinary school?

D: It's because you are lazy and when you get to graduation day you finally come to this school. Ordinary schools don't want us if you are lazy. You are supposed to be here to do things you haven't done in the ordinary class so that you can get out again. 
In this sequence of the interview, Daniel shows that he has worked out what he has to do to 'get out'. He is just doing what is expected because he has to. Several of the informants expressed that they behaved more desirably in order to move back home. Some also talked about knowing how to get what they wanted as quickly as possible. For instance, Melissa talked about having 'to clean and tidy your room. Then you must cook food and behave so you can be out with friends and have your mobile.' She said that she tried to show that she could behave so that she could 'get my own apartment, that is my goal.'

In these examples of secondary adjustment, the youths are actors who are capable of reformulating and turning away from learned helplessness and open protests (Goffman 1967).

\section{Using time as a starting point}

Another way of showing resistance to categorisation and presenting themselves as accountable individuals in the interviews was to use time as a resource and as a new starting point. This is a variation of the previous examples of 'total adjustment' although here the youths do not connect themselves with problem categories. The youths may have had problems in the past - at home but now they are in an institution, which makes it possible to claim that they have changed. Furthermore, in these cases the activities in the institution are talked about as a starting point for being somebody else; a more 'normal' or 'desirable' youth. The following example is taken from an interview with Jonathan, aged 13:

S: What is the best about being here? Is there anything like that?

$\mathrm{J}$ : Yes. What I think is the best about being here is that you can relax and so on and forget all your troubles $(\mathrm{mm})$. That's why I came here, to forget everything and start all over again. (Okay) and leave all the old stuff behind me. Start a new life in a way.

S: So that is your goal while here?

J: Yes, simply to start a new life and forget everything I have done and simply, yes, to start afresh.

S: Does that mean that you are not moving back home again? That you should move to another place?

J: I would prefer to move back home after being here because I have realised that everything I did was stupid and that perhaps I can start all over again.

Here Jonathan talks about doing wrong and doing right and says that he did 'stupid' things before, but that the child welfare institution has functioned as a place where he has changed his behaviour, has become aware of his mistakes and is in a position to 'start all over again'. Furthermore, Jonathan describes his situation as a process of change from something deviant to 
something normal. This change is explained as both a necessity and an opportunity to be able to move back home and he claims that he now is capable of behaving in the 'right' way.

In the following interview, Elisa (14 years) argues in a similar way:

S: What did you think when you came here, when you were new here at the beginning?

E: I didn't want to be here at all. First they said that I were going to a foster family and then suddenly I was in a juvenile home. Yes, but why the f... should I get treatment? I was really pissed off and very negative towards this place for a start. They said that I should be here for a month and then when I arrived, because they forced me, they said that I should be here at least six months.

Elisa gives her point of view and describes that she 'for a start' felt tricked and did not really understand why she had to stay. To begin with, she felt 'forced' into staying and did not agree that she needed 'treatment'. Later in the interview, she says that despite this beginning, she has been helped by the staff.

In the interviews, Jonathan and Elisa use time to point out how they have changed. Accordingly, the time spent in the institution has enabled them to present themselves as 'normal' in that they resist a client identity. It is important to recognise how the logic in the teenagers' talk contributes to them becoming 'normal', i.e. they present themselves as a part of the solution (Munford \& Sanders 2008).

\section{Non-participation as a resource}

The analysis of the interviews reveals another way of resisting a client identity, namely distancing oneself from the activities or decisions connected with placement in the institution. The youths did not see themselves as having a good or bad client-identity at all. In the following example, 13-year-old Jasper expresses that he has not participated in the planning or signed a contract regarding his stay:

S: What happens in these meetings?

J: Writing a contract about whether you want to stay at the school or not.

S: Why should you have such a contract?

$\mathrm{J}$ : I don't know. They only use it at this school. The contract is a bit ridiculous.

S: Do you think so?

J: Yes, I do. Damned ridiculous.

S: Do you know what it says in yours?

$\mathrm{J}$ : Yes, I have absolutely not written it myself!

S: No. But what does it say?

J: Much, for example the first time, the first year it said that I should think about my temper and that I shouldn't be angry about everything and so on. 
In this example, Jasper distances himself from the actions of the institution. He indicates resistance to the term and tool 'contract' and points out that 'I have absolutely not written it myself'. In other words, the contract is not his, even if it has his name on it. By rejecting any attempts to govern or control him, he distances himself from the institutional agenda and the construction of a client who participates in clienthood by signing a contract. Furthermore, he says that they have had meetings about 'whether you stay at the school or not'. He seems to understand that he has to approve the descriptions in order to remain at the institution. Here he connects his presence in the institution to the context and the demands of accepting the descriptions of his problems as a presumption to be helped. Approval of the contract allows him entrance to the activities, which can later function as a way back to ordinary school. On the other hand, refusal of the contract can exclude him and make the way back longer and more difficult. Approval of the contract and acting in a desirable manner implies that he accepts the identity constructed in the contract. However, Jasper doesn't want that; when he says that he is not part of all that, it can be interpreted as refusing the categorisation. Jasper shows that, although he understands the institution's 'game', rejecting the contract means that he can see himself as accountable and not ridiculous. This non-participation can be interpreted as resistance to being defined as different or deviant.

\section{Others' bad behaviour}

Another strategy that the informants used to present themselves in relation to the institution and to show resistance was to distance themselves from others, i.e. the 'troubled'. In the following extract, Jennifer, aged 14, talks about herself as someone who does not behave in the same way or shares the same problems as other adolescents placed in child welfare institutions (cf.

McMurray et al. 2011):

S: Here there are people who have been here for a long time and for only a short time. (Yes) What about that?

$\mathrm{J}$ : Very strange. It works well anyway, but it is also a pain. I think it is hard when people have only just arrived. When you arrive, you feel rather bad (mm) and some people cut their arms, which is not nice (No) for everyone to see.

In this example, Jennifer talks about other teenagers' bad behaviour. By talking about some people cutting their arms and arguing that others have more problems, she distances herself from 'deviant' behaviour or identity. Moreover, she talks about deviance from an outside perspective and does not include herself in such a deviant identity. Other 'people' are talked 
about as different and can be categorised as deviant. She uses other youths to present herself as accountable, i.e. identity becomes relative and she can present herself as someone who functions well in comparison to others in the collective. Noah, aged 12, uses the same arguments when he suddenly whispers:

'I don't want to talk too loud because he (another boy) might be listening. He is very annoying and every time you say something, he wants to fight and make trouble.'

Noah makes it clear that he reacts when another boy annoys him. He also uses the boy to present himself as a calm and good person.

It is not only other teenagers who can be used in this way. Jasper, aged 13, compares his previous 'ordinary' schoolteachers with the teachers at the institution. His response is an example of how he presents himself as accountable through comparisons with a teacher, who he thinks acts in a peculiar way.

S: Are there any differences between how Janice and Jeff (his current teachers) do things, compared to the ordinary school?

J: No, only that sometimes they use [palm-back V-sign].

$\mathrm{S}: \mathrm{Mm}$

$\mathrm{J}$ : And then I point back. And that is very peculiar.

$\mathrm{S}$ : Is it peculiar?

J: Although I usually just look up and try to seem surprised and then I put up my hand, and tell them they use [palm-back V-sign].

In this example, Jasper presents himself as a person who knows how to behave, i.e. he does the right thing. In his eyes, it is the adults who misbehave, in that he regards himself as behaving in a better way. In the interview he can construct an image of himself as a good pupil by saying, 'Although I usually just look up and try to seem surprised that 'they' use [palm-back V-sign]'. The account can be interpreted as an example of how a position as a 'good pupil' in contrast to others, is possible. It also shows how Jasper indicates that he is able to tell the difference between normal and 'peculiar' (deviant) behaviour.

In Jasper's, Noah's and Jennifer's accounts, it is the teachers or other teenagers who act incorrectly. In these examples, they distance themselves from the peculiar behaviour by saying that it is the others who behave in an odd way. In the interviews they create their own accountability by using others' deviant behaviour and answer back if anyone thinks that they do 
peculiar things. Making use of the bad behaviour of 'others' is here interpreted as a way of answering back to resist clientification (Messmer \& Hitzler 2011).

\section{BECOMING ACCOUNTABLE}

In this article, we have analysed interviews conducted with young people in relation to child welfare institutions. We were particularly interested in constructions of ordinariness, i.e. the categorisation of a 'normal' identity in contrast to an identity of clienthood that is intimately connected with child welfare institutions. In the interviews, the youths accepted that they were different and needed interventions, although they sometimes argued against being positioned as a problem. In this context, the interview is understood as an arena for investigating the possibilities and limitations of (re)claiming a 'normal' identity. We also investigated how the youths responded to stigmatised identities (Juhila et al. 2003; Juhila 2004).

The analysis reveals four different types of argumentation that make it possible to become a competent and accountable person and resist embedded, stigmatised identities. We have chosen to call these arguments discursive resistance. We also identified what we have called secondary adjustment, which is a kind of surface adaptation that also can be seen as a resistance to making the institutional goals your own. Another kind of discursive resistance is to use time to distance oneself from something, i.e. I was troublesome before, but am not any more.

A third type of discursive resistance that emerged in the interviews was to distance oneself from what is happening by non-participation. The adolescents did not talk about themselves as active participants and refused to accept the institutional plans or artefacts.

Furthermore, the informants made references to others' bad behaviour (other youths or teachers) to position themselves as normal (McMurray et al. 2011). In their argumentation, they also showed that they were aware of the expectation of 'normal' behaviour. We do not interpret this as a projection in a psychological sense, as for example Forrester et al. (2008) do, but a conscious choice to argue that the youth does not belong to the category of clients placed in this setting.

The institution is also used as evidence that the youth has changed. Here the youths use the setting in the supposed or 'right' way, i.e. they show that they could use the institution, behave in expected ways and be transformed from a deviant youth into a normal youth. In this type of argumentation, the context (time and place) is used as both an explanation for having 
had problems and as a solution. After having been in the institution for some time, the youths become accountable individuals.

These four different kinds of discursive resistance were constructed in the interview interactions between the interviewer and the youths. They were not expressed as open protest or a psychological defence of unwanted feelings. This kind of resistance could be seen as an opportunity to construct oneself as an accountable person, rather than as a client. The youths used these different kinds of discursive resistance to avoid acceptance of stigmatised identities/clientification (Juhila 2004; van Nijnatten 2010). This strategy allowed them to retain their 'normal' identity and present themselves as accountable. Presenting oneself as accountable, rather than belonging to a client or deviant category, seemed to be important to the adolescents.

\section{CONCLUDING REMARKS}

This article exposes and describes the various ways in which youths who are objects for child welfare interventions use discursive resistance; it shows how it is possible to resist stigmatising identities even when placed in a welfare institution. By using different discursive arguments, the interviewed youths relate their talk about themselves to the institutional context and position themselves as competent actors. They resist the developmental thinking that they must become responsible actors. They do not become participants in society because they are already participating. These participants use their voices and create a positive identity, which can function as resilience - just as Ungar (2004) and Eide \& Winger (2005) concluded in their research. A positive identity can also make them less vulnerable to ill-treatment, as Cairns \& Brannan (2005) claim. At the same time, the youths used discursive resources in a pragmatic way in order to maintain consensus and compliance. Understanding this very implicit way of showing discursive resistance is important in social work practice where possibilities of reclaiming accountability are in focus. This kind of discursive resistance could also be a way of creating declientification (Messmer \& Hitzler 2011; Cedersund \& Säljö 1993) in social work. Accepting resistance to 'troubled' identities constructs an individual who is accountable and focuses on personal strengths. According to Munford \& Sanders (2008) this behaviour is rare. Individuals who are accountable are recognised as actors who become visible through their resistance to what threatens their motives and what is at stake for them, i.e. their normality. In the interviews, the youths resisted categorisations and offered identities (Juhila 2004; van Nijnatten 2010); they managed to present themselves as 'normal' teenagers. In general, young 
people want to be responsible for their own lives and resist that which conflicts with their own motives and their personal stakes. In other words, they can resist social workers' or interviewers' agendas to create their own, despite existing power-based relationships (McLeod 2007).

\section{REFERENCES}

Best, J. (1994) Troubling Children: Studies of Children and Social Problems. Walter de Gruyter, New York.

Cairns, L. \& Brannen, M. (2005) Promoting the human rights of children and young people the 'Investing in Children' experience. Adoption and Fostering, 29, 78-87.

Cedersund, E. \& Säljö, R. (1993) Bureaucratic discourse, conversational space and the concept of voice. Semiotica, 97, 79-101.

Eide, B. \& Winger, N. (2005) From the children's point of view: methodological and ethical challenges. In: Beyond Listening: Children's Perspectives on Early Childhood Services (eds A. Clark, A. Kjorholt \& P. Moss), pp. 71-89. Policy Press, Bristol.

Forrester, D., McCambridge, J., Waissbein, C. \& Rollnick, S. (2008) Child risk and parental resistance. British Journal of Social Work, 38, 1302-1319.

Giroux, H.A. (1983) Theories of reproduction and resistance in the new sociology of education: A critical analysis. Harvard Educational Review, 53 (3), 257-293.

Goffman, E. (1967) Interaction Ritual: Essays on Face-To-Face Behavior. Anchor Books, New York.

Goffman,E. (1968) Asylums: Essays on the Social Situation of Mental Patients and Other Inmates. Penguin, London.

Goffman, E. (1990) The Presentation of Self in Everyday Life. Penguin, London.

Gubrium J. F. \& Holstein J. A (2001) Introduction: Trying times, troubled selves. In: Institutional Selves:Troubled Identities in a Postmodern World (eds J.F. Gubrium \& J.A. Holstein) pp. 1-20. Oxford University Press, Oxford.

Hall, C., Slembrouck, S. \& Sarangi, S. (2006) Language Practices in Social Work. Categorisation and Accountability in Child Welfare. Routledge, London.

Holstein, J.A. \& Gubrium, J.F. (1995) The Active Interview. Sage, Thousand Oaks.

Högberg, R. (2011) Cheating as subversive and strategic resistance: vocational students' resistance and conformity towards academic subjects in a Swedish upper secondary school. Ethnography and Education, 6 (3), 341-355

Järvinen, M. \& Mik-Meyer, N. (eds) (2003) At skabe en klient - Institutionella identiteter $i$ socialt arbejde. [Creating client-institutional identities in social work] Hans Reitzels førlag, Køpenhamn .

Juhila, K. (2004) Talking back to stigmatized identities: negotiation of culturally dominant categorizations in interviews with shelter residents. Qualitative Social Work, 3 (3), 259275.

Juhila, K., Pösö, T., Hall, C. \& Parton, N. (2003) Introduction: Beyond a universal client. In: Constructing Clienthood in Social Work and Human Services: Interaction, Identities and Practices. (eds C. Hall, K. Juhila, N. Parton, \& T. Pösö) 11-24. Jessica Kingsley, London.

Kelly, P. (2006) The entrepreneurial self and 'youth-at-risk': exploring the horizons of identity in the twenty-first century. Journal of Youth Studies, 9, 17-32. 
Markström, A-M. (2010) Talking about children's strategies to show resistance in preschool. Journal of Early Childhood Research, 8 (3) 303-314.

McFadden, M.G. Resistance to schooling and education outcomes: questions of structure and agency. British Journal of Sociology in Education, 16 (3), 2923-308.

McLeod, A. (2007) Whose agenda? Issues of power and relationship when listening to lookedafter young people. Child \& Family Social Work, 12, 278-286.

McMurray, I., Connolly, H., Preston-Shoot, M. \& Wigley, V. (2011) Shards of the old looking glass: restoring the significance of identity in promoting positive outcomes for looked-after children. Child \& Family Social Work,16 (2), 210-218.

Messmer, H. \& Hitzler, S. (2011) Declientification: undoing client identities in care planning conferences on the termination of residential care. British Journal of Social Work, 41 (4), 778-798.

Munford, R. \& Sanders, J. (2008) Drawing out strengths and building capacity in social work with troubled young women, Child \& Family Social Work, 13 (1), 2-11.

Russell, L. (2011) Understanding Pupil Resistance: An Educational Ethnography. E \& E Publishing, Essex.

Severinsson, S. (2010) Unga i normalitetens gränsland. [Adolescents in the borderline of normality.] Dissertation. Linköping University.

Thomas, J. \& Holland, S. (2010) Representing children's identities in core assessments. British Journal of Social Work, 40, (8), 2617-2633.

Trondman, M. 1999. Kultursociologi i praktiken. [Cultural sociology in practice.] Studentlitteratur, Lund.

Ungar, M. (2001) The social construction of resilience among 'problem' youth in out-ofhome placement: a study of health-enhancing deviance. Child and Youth Care Forum, $\mathbf{3 0}$ (3), 137-154.

Ungar, M. (2004) Nurturing Hidden Resilience in Troubled Youth. University of Toronto Press, Toronto.

Ungar, M. (2005) Pathways to resilience among children in child welfare, corrections, mental health and educational settings: navigation and negotiation. Child and Youth Care Forum, 34 (6), 423-444.

Van Nijnatten, C. (2010) Deadlocked dialogues in child welfare. British Journal of Social Work, 40, 826-840.

Willis, P. (1977) Learning to Labour: How Working Class Kids Get Working Class Jobs. Saxon House, Farnborough.

Wood, L.A. \& Kroger, R. O. (2000) Doing Discourse Analysis. Thousand Oaks, CA: Sage. 